\title{
Old Romanian pluralized mass and abstract nouns
}

\author{
Gabriela Pană Dindelegan* \\ Faculty of Letters, University of Bucharest, Str. Edgar Quinet 5-7, Sector 1, 010017 Bucharest, Romania \\ "Iorgu Iordan - Al. Rosetti" Institute of Linguistics, Calea 13 Septembrie 13, 050711 Bucharest, Romania
}

Article info

History:

Received May 8, 2017

Accepted June 3, 2017

Published September 30, 2017

Key words:

old Romanian

mass noun

abstract noun

pluralization

lexical plural

\begin{abstract}
The analysis of a rich old Romanian corpus shows that the 'pluralization' of mass and abstract nouns is extremely frequent in old Romanian. The semantic effects of pluralization are similar for mass and abstract nouns, consisting in the creation of denotative and/or connotative semantic variants. Of the plural endings, - uri is specialized for the pluralization of mass nouns in Daco-Romanian. The evolution of the ending - uri illustrates the specific process by which a grammatical (plural) morpheme is converted into a lexical morpheme (the so-called 'lexical plurals'). 'Lexical plurals' have isolated occurrences in other Romance languages, but they have not reached the spread and regularity they display in Romanian.
\end{abstract}

\section{Introduction}

Mass and abstract nouns have common semantic and morphosyntactic characteristics, which accounts for the fact that they are engaged in common phenomena (see 'pluralization' and its effects), as well as that they are analysed together (as in this article).

The objective of this article is to examine the phenomenon of pluralization of mass and abstract nouns, and its semantic and grammatical effects, on the basis of a rich corpus of old Romanian (1560-1780).

\section{Mass nouns}

\subsection{Characteristic features}

The inherent [+mass] feature influences the grammatical behaviour of nouns, in the sense that mass nouns are distinguished from prototypical ones as far as their inflection (Nedelcu, 2013, p. 260-261) and morphosyntax are concerned (Pană Dindelegan, 2016b, p. 324-332). One inflectional feature of mass nouns is represented by their inclusion in the class of uncountable nouns, most mass nouns having no plural [singularia tantum nouns $(1 \mathrm{a}-\mathrm{d})]$ and, only very rarely, having no singular form [pluralia tantum nouns $(2 a-b)]$.

(1) a. unulu amu auru dăruindu, şi altulu argintu, e altulu păine one now gold give.Ger and another silver and other bread 'one giving gold now, and another one silver and yet another one bread'

$$
\left(\mathrm{CC}^{2} .1581,321 / 1\right)
$$

b. Și v-am dat voauo grîu și vin și unt and CL.DAT.2PL=have given you.DAT grain and wine and butter 'and I gave you grain and wine and butter'

$\left(\right.$ CLRV, 172 $\left.{ }^{\mathrm{r}}\right)$

\footnotetext{
*Email address: g_dindele@yahoo.com.
} 
c. ca să nu mai aducă sînge de capră și de vițel și CA S $\breve{A}_{\text {SUB }}$ not more bring blood of goat and of calf and cenușe de juncu ash of young.ox 'to no longer bring goat and calf blood and the ash of young oxen' (Ev.1642, 317)

d. Miiare, lapte din pămînt vor izvorî honey milk from ground will spring 'honey, milk will spring from the ground'

$$
\text { (DPar.1683, III/134 }{ }^{\mathrm{r}} \text { ) }
$$

(2) a. era tremiși în cetate să were sent in city $\breve{S A}_{\text {SUB }}$ 'they were sent in town to buy food'

cumpere bucate buy food

$$
\left(\mathrm{CC}^{2} .1581,151\right)
$$

b. Și le-au trimis and CL.DAT.3PL=have sent of enough food 'And they sent them food to have enough'

(DPV.1673, 541)

Another feature of mass nouns, which singles out Romanian in Romance, concerns their ability to occur in argument positions without a determiner or, in other words, in 'bare' nominal phrases [see (3a)]. Just like Spanish, Portuguese and southern Italo-Romance (see Ramat \& Ricca, 2016, p. 52-53), Romanian has not developed a partitive article. Differently from modern Romanian, in old Romanian, besides structures without a determiner (3a), structures with partitive de in argument positions also occur $[(3 \mathrm{~b}-\mathrm{c})$; Pană Dindelegan, 2016a, p. 330-331], constructions which disappeared from standard use at a later date.

(3) a. Cerșu elu să bea apă

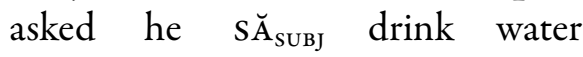
'he asked to drink water'

$$
\left(\mathrm{CC}^{2} .1581,158\right)
$$

b. Să bea de apa ce-i voi da eu $\breve{S A}_{\text {SUBJ }}$ drink of water that=CL.DAT.3sG will give I 'to drink from the water that I shall give him'

\section{$\left(\mathrm{CazV} .1643,158^{\mathrm{v}}\right)$}

c. Că unii aleg de bucate: un fealiu de bucate mănîncă because some choose of food one kind of food eat 'because some choose the food: they eat one kind of food'

$$
\left(\mathrm{CC}^{1} .1567,194^{\mathrm{r}}\right)
$$

\subsection{Pluralization of mass nouns}

Customarily, the pluralization of mass nouns triggers changes in meaning, which, implicitly, lead to 'demassification' (4a). Pluralization can sometimes interfere with gender variation [marmurile $e_{\mathrm{F} / \text { N.PL }}$ vs marmurii $_{\mathrm{M} . \mathrm{PL}}$ 'marble.PL' $(4 \mathrm{~b}-\mathrm{c})$ ], with the same semantic-grammatical effect: change of meaning and implicitly, 'demassification'.
(4) a. să-șu
ia pre
cale
numai un
toiagu, nece
bucate, $S \breve{A}_{\text {SUBJ }}=$ CL.REFL.DAT.3PL take
on way
only
staff neither food 
nece pîine, nece pre brăne arămi $^{1}$

nor bread nor on belts copper.PL

'to take for the trip only a staff and no food, no bread, no belts adorned with copper' (Ст.1560-1, 79v)

b. daca s-au luat marmurile de pre gropniță when CL.REFL.ACC.3PL $=$ have taken marble.PL.DEF of on grave au luminatu soarele ș-acolo has light.PPLE sun.DEF also=there 'when they lifted the marble [tombstones] from the grave the sun lit that place too' (Cron.1689, 98)

c. stîlpii şi marmurii poles.DEF and marble.PL.DEF 'the poles and the marble [slabs]' (DVs.1682-6, 96 ${ }^{\mathrm{r}}$ )

Of the plural endings, there is one which is specialized for the pluralization of mass nouns, attaching to both feminine and neuter mass nouns. This is the ending - uri, which, attached to the mass noun, ensures its pluralization and, implicitly, its change in meaning ${ }^{2}$. From a functional perspective, with such uses, the ending -uri is close to a lexical suffix, as it does not change only the inflectional features of the noun, but also its meaning. This phenomenon takes place exclusively in the dialects spoken north of the Danube ${ }^{3}$ and can be traced back to the beginning of the $17^{\text {th }}$ century, having its first attestation in 1620 [Frâncu, 1982; (5a)]; later, examples multiply and diversify $(5 \mathrm{~b}-\mathrm{j})$. The following types of pluralization can be distinguished:

(i) - uri is attached to certain roots of feminine mass nouns ${ }^{4}$, and its effect is either a new denotative meaning, "type, variety of a certain substance" ( $5 a-j)$, or a pejorative connotative value (6). But while the first category is old in Romanian (attested at the beginning of the $17^{\text {th }}$ century), the second one has its first attestations in modern Romanian ${ }^{5}$.

(5) a. Si carne $e_{1}$ o dede tătarilor de o $m<\hat{\imath}>n c a r a ̆$, și ziseră că $<$ este $>$ mai dulce de toate cărnurile pre $_{2}$ lume $^{6}\left(\mathrm{~A} .1620,24^{\mathrm{v}}\right)$

'And they gave the Tartars meat to eat and they said that it was sweeter than all the meats in the world'

b. Toate cărnurile sărate, cum spete, limbi, cîrnați, păstrămi (CBuc.1749, 52v)

'all the salty meats, such as shoulders, tongues, sausages, pastramis'

c. invățătură de a face dulcețuri (CBuc.1749, 59²)

'knowledge to make jams'

d. cînd va fi aproape de fiert, pune-i o mînă de erburi tocate (CBuc.1749, $6^{\mathrm{r}}$ )

'when it is close to the boiling point, add some chopped herbs'

e. călțun cu sîrmă și cu alte mătăsuri (CDicț.1691-7, 136)

'shoe with wire and other silks'

\footnotetext{
${ }^{1}$ One should separate the plural from the singular etymological form arame of the mass noun (darul carele de la ei veți lua: aur, argint, arame 'the gift that you will take from them: gold, silver, copper', P0.1582, 190; poarta cea de arame 'the copper gate', Ev.1642, 209).

${ }^{2}$ Maiden (2014, p. 41) is the first to describe this new function of -uri as a 'derivational' rather than a grammatical one.

${ }^{3}$ Maiden (2015, p. 46) has noticed that, in contrast to Daco-Romanian, South-Danubian dialects (Megleno-Romanian and Aromanian) do not display the correlation between the extension of -uri to plural feminine nouns and the semantics of mass nouns, as -uri also occurs with non-mass nouns.

${ }^{4}$ See the complete list of feminine nouns with - uri in Maiden (2015, p. 44-45).

${ }^{5}$ For modern Romanian, see the detailed description of Avram (2003-2004).

${ }^{6}$ The two different forms occur in the same example; different meanings and, implicitly, different lexical units correspond to them.
} 
f. învățătură de a face multe feliuri de sălături (CBuc.1749, 49v)

'knowledge to make many types of salad'

g. căci sîngiuri multe ai vărsat preste pămînt înaintea Mea (вв.1688, 302/XXII)

'because you shed much blood on earth in front of Me'

h. țîitoare de unsoruri (CDicț.1691-7,321)

'recipient for grease'

i. Și să mănînce cu adzîmă nedospită și cu verdețuri amară (Cron.1689, 47)

'and they should eat it with unleavened bread and with bitter herbs'

j. baie de zoaie, scăldătoare de zoiuri (CDicț.1691-7, 493)

'bath of slops, tub of slops'

(6) delicatețuri 'delicacy.PL' ( $\leftarrow$ delicatețe 'delicacy'), gentilețuri 'acts of kindness' $(\leftarrow$ gentilețe 'kindness'), politețuri 'acts of politeness' ( $\leftarrow$ politețe 'politeness'), străinătățuri 'foreign countries' $(\leftarrow$ străinătate 'foreign countries'), tandrețuri 'acts of tenderness' ( $\leftarrow$ tandrețe 'tenderness')

(ii) -uri attaches to some roots of neuter mass nouns, adding a different denotative effect: (i) "objects made from that substance" (7a-c); (ii) "sorts" (7d).

(7) a. Au nu cu arginture te-ai tocmitu cu mine? (ст.1560-1, 42 )

'Have you not bargained with me with silver coins?'

b. Cînd vei vrea să speli arginturile (CBuc.1749, 62 ${ }^{\mathrm{r}}$ )

'When you will want to clean the silverware'

c. Untul de ceară (...) păstrează foarte bine metalurile de rugină (CBuc.1749, 63v)

'Wax butter protects metal objects from rust very well'

d. să să bea ca și alte vinuri noao (CBuc. $1749,53^{\mathrm{v}}$ )

'one should drink them just other new types of wine'

Similar phenomena of 'lexical plurals' have been noticed in other Romance varieties (Asturian, Leonese, Neapolitan), being interpreted in the same way or differently (see Ramat \& Ricca, 2016, p. 61). However, we need to point out that this phenomenon has not gained anywhere else the extension and regularity it has in the Romanian variants spoken north of the Danube.

In conclusion, for Romanian, in the case of feminine nouns, -uri functions mostly with a lexical role, being connected to the roots of mass nouns ${ }^{7}$, while, in the case of neuter nouns, the ending -uri (or the inflectional morpheme sequence $-u r+-i^{8}$ ) functions mostly as a grammatical device, marking the plural (the type joc - jocuri 'game - games', loc - locuri 'place - places', lucru - lucruri 'thing - things', tablou tablouri 'painting - paintings') and only in rare cases, it also functions as a lexical suffix, when attached to the roots of mass nouns (arginturi 'silverware', metaluri 'metal objects', vinuri 'types of wine').

\footnotetext{
${ }^{7}$ Without having the same extent, a similar use occurs in the case of plural feminine forms in -(a)le: the type cosmeticale 'cosmetics', istericale 'hysterical fits', mitologicale 'mythologies', politicale 'politics', zaharicale 'sweets' (Pană Dindelegan, 2009, p. 19), where the ending - (a)le, next to its association with the value "plural feminine", also bears a supplementary lexical value, adding a pejorative, ironical connotation to the formation. The process is similar, consisting in the conversion of a plural marker into a lexical marker.

${ }^{8}$ The type of analysis timp-ur-i, put forward in Maiden (2016a,b), allows one to detach two distinct plural morphemes: $u r-$ and $-i$, both indicating the feminine. Maiden's solution (2016a,b) takes into account the historic date, according to which, in the $16^{\text {th }}$ century, in the inflectional complex -ure, the plural ending $-i$ replaces the older ending $-e(-$ ure $>-$ uri: timpure $>$ timpuri 'times'). The change $-e>-i$ follows the same process observed with other feminine nouns (plurals like bălți 'pools', boli 'diseases', gropi 'holes', răni 'wounds', roți 'wheels', tălpi 'soles' replaced the older forms balte, boale, groape, rane, roate, talpe; many other non-standard forms like băniți 'units of measure', catarămi 'buckles', crătiți ' pots', făbrici 'factories', hăini 'coats', înghețăți 'ice creams' are used in parallel with older standard forms in $-e$ ). The double plural marking, with co-occurring inflectional markers, supports the idea that the Romanian plural is "hypermarked" or characterized by "extended exponence"; this means that plural marking is not limited to the ending, but also affects the root, making segmentation very difficult.
} 


\section{Abstract nouns}

\subsection{Characteristic features}

Just like mass nouns, abstract nouns are inflectionally characterized by the fact that they are uncountable and morphosyntactically by their preferential occurrence in argumental structures with a bare determiner. Both characteristics have been attested since old Romanian.

\subsection{Pluralized abstract nouns (the type cinste 'honesty', miloste 'mercy'))}

The richness of abstract formations of Romanian, in general, and of old Romanian, in particular, has already been noticed (FCLRV; Pană Dindelegan, 2017), and it mainly represents the outcome of the rich inventory of abstract suffixes, many of them highly productive, and of the synonymy and competition among suffixes.

The propensity of old Romanian to frequently 'pluralize' abstract nouns is remarkable: instead of singularia tantum uses, characteristic for modern Romanian, abstract nouns occur frequently with a plural form $^{9}$ (see also Frâncu, 2009, p. 28). For the formations with a Slavic correspondent, one explanation that was given is that they were 'modelled after the plural form of corresponding Slavic words' (Candrea, 1916, p. CLXXXII).

Quite frequently, pluralized abstracts occur in a cascade; see (8), Chivu (1993, p. 176).

(8) a. Carile sînt năravurile trupulu<i> ceal<ea > realele? Măriile, trufele, mîniile, uciderile, curviile (...), saltăturile (...), urgiile, clevetele (Cs.1609-18, 114 ${ }^{\mathrm{v}}$ )

'Which are the bad habits of our bodies? Acts of haughtiness, pride, fits of anger, killings, acts of fornication, dances, acts of wrath, gossip'

b. Nu spunem strîmbătățile (...), clevetirile, voile veghiiate, fățăriile, mozaviriile, vînzările și pîrăle ce facem unul altuia (AD.1722-5, 85)

'We do not tell about the wrong doings, intrigues, favourings, hypocrisies, calumnies, acts of treason and denounces that we cause to one another'

The plural is either identical with the singular, indicating that the noun is invariable ( $\mathrm{SG} \equiv \mathrm{PL}$ blindeațe 'gentleness', $\mathrm{SG} \equiv \mathrm{PL}$ cinste 'honour', $\mathrm{SG} \equiv \mathrm{PL}$ datoare 'duty', $\mathrm{SG} \equiv \mathrm{PL}$ dragoste 'love', $\mathrm{SG} \equiv \mathrm{PL}$ pace 'peace' (9a$\mathrm{g}$ ), or different from the singular, following the model of feminine nouns with the singular in $-e$ [cinste - cinsti 'honour - honours', foamete - foameți 'hunger - hunger.PL', miloste - milosti 'mercy - mercy.PL', năpaste - năpăștil/năpasti 'calamity - calamities', pace - paci 'peace - peace.PL', ruşine - rușini 'shame shame.PL' $(10 \mathrm{a}-\mathrm{O})]$ or of feminine nouns with the singular in $-\breve{a}$ and the plural in $-e$ [măreață - măre (a)țe 'haughtiness - haughtiness.PL', sfadă - sfade 'quarrel - quarrels', slava - slave 'glory - glories' $(11 \mathrm{a}-\mathrm{c})$ ] or in -i [pîră - pîri 'denounce - denounces', pizmă - pizmi 'envy - envies', gîlceavă - gîlcevi 'quarrel - quarrels', vrajbă - vrăjbi 'wrath - wraths' $(1 \mathrm{~d}-\mathrm{h})]$. Some pluralized abstracts have an oscillating form in plural contexts, occurring either as invariable nouns, or with a form that is different from the SG (PL cinste // cinsti 'honour.PL', PL dragoste // dragosti 'love.PL', PL pace // paci 'peace.PL', PL pizme // pizmi 'envy.PL').

(9) a. Ascultați, oameni iubitori la oameni, adîncul și blîndeațele ${ }_{\mathrm{PL} . \mathrm{DEF}}^{10}$ ce feace Dumnedzău (CLRV.1621-33, 195/170 )

'Listen, humans loving humans, to God's deeds'

b. ca să te ajute cu bani și cu alte multe cinste PL $_{\mathrm{PL}}$ (Dî.1600, XXXII)

'to help you with money and with many other honours'

\footnotetext{
${ }^{9}$ One should notice that all the abstract nouns in $(9)-(11)$ no longer occur with a plural form in modern standard Romanian.

${ }^{10}$ The other formations with the abstract suffix $-e(a)$ țe are also included here: $\mathrm{SG} \equiv \mathrm{PL}$ bătrineațe 'old age', tinereațe 'youth'.
} 
c. Unde-s cinstele $e_{\mathrm{PL} . \mathrm{DEF}}$ ceale de frunte? (Mărg.1691, 145 ${ }^{\mathrm{r}}$ )

'Where are the most important honours?'

d. vor inpărți cinstele $e_{\mathrm{PL} . \mathrm{DEF}}$ (FN.1693-704, 167)

'they shall divide the honours'

e. pentru dragostele $e_{\mathrm{PL} . \mathrm{DEF}}$ muierești (Cron.1689, 27)

'for women's love'

f. Doamne, miluiaşte noi cu pacele PL.DEF $_{\text {tale }}\left(\mathrm{CL} .1570,8^{\mathrm{r}}\right)$

'God, have mercy on us with your peace'

g. nu iaste mai bună decîtu pacele PL.DFF si dragostele $_{\mathrm{PL} . \mathrm{DEF}}\left(\mathrm{CC}^{2} .1581,129 / 33\right)$

'it is not better than peace and love'

(10) a. cumulte cinsti $i_{\mathrm{PL}}$ cinstiră $\left(\mathrm{CV} .1563-83,49^{\mathrm{v}}\right)$

'they honoured them with many honours'

b. şi-i facea trei cinsti $i_{\mathrm{PL}}$ și trei ruşini $i_{\mathrm{PL}}\left(\mathrm{FD} .1592-604,599^{\mathrm{r}}\right)$

'and he did three honourable and three shameful deeds'

c. la alte cinsti $i_{\mathrm{PL}}(\mathrm{PA} \sim 1630, \mathrm{CAP} .250)$

'for other honours'

d. mai sus (...) decît toate cinstile $_{\mathrm{PL} . \mathrm{DEF}}$ (DPar.1683, III/98 ${ }^{\mathrm{r}}$ )

'more than all the honours'

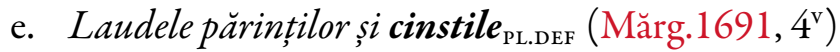

'the parents' praises and their honour'

f. fară alte cinsti $i_{\mathrm{PL}}$ (FN.1693-704, 203)

'without other honourable acts'

g. î isint acestea necinst $i_{\mathrm{PL}}$ (FN.1693-704, 376)

'these are his dishonourable acts'

h. vor fifoameți $i_{\mathrm{PL}}$ ș griji ( СТ.1560-1,99 $)$

'there will be times of famine and worries'

i. Lăsa-voiu pre voi omet și geru greu și foameți $\mathrm{iL}_{\mathrm{PL}}$ și pară (CLRV.1621-33, 195/171 ${ }^{\mathrm{v}}$ )

'I shall set upon you snow and harsh frost and times of famine and fire'

j. plinră de milosti $i_{\mathrm{PL}}\left(\mathrm{CV} .1563-83,63^{\mathrm{v}}\right)$

'full of mercy'

k. și mai mare năpăşti $i_{\mathrm{PL}}$ ne face (Dî.1599, XVIII)

'and it causes us greater calamities'

1. cîndu întru năpasti $i_{\mathrm{PL}}(. .$.$) cădeți \left(\mathrm{CV} .1563-83,55^{\mathrm{r}}\right)$

'when disasters happen to you'

m. să lăsați (...) paci p $_{\mathrm{PL}}$ si tocmeale bune (Dî, CIII)

'to leave peace and good agreements behind'

n. Pacile $_{\mathrm{PL} . \mathrm{DEF}}$ lumiei tale dăruiaște besearecilor tale $\left(\mathrm{CL} .1570,42^{\mathrm{v}}\right)$

'give the peace of your world to your churches'

o. s-au prinsu la niscare rușini $i_{\mathrm{PL}}$ (Mărg. 1691, 1 $1^{\mathrm{v}}$ )

'they agreed to do some shameful deeds'

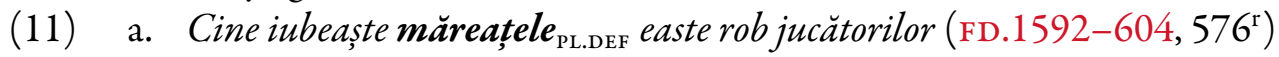

'Whoever loves acts of haughtiness is a slave of jesters'

b. Și începu fratele a face sfade $e_{\mathrm{PL}}$ cu starețul, dosădindu-l și zîcînd (DVs.1682-6, 56 ${ }^{\mathrm{v}}$ )

'And the monk started quarreling with the prior, making him sad and saying'

c. le făgăduesc mari slave $\mathrm{PL}_{\mathrm{PL}}$ si cinsti (FN.1693-704, 52)

'I promise them great praises and honours'

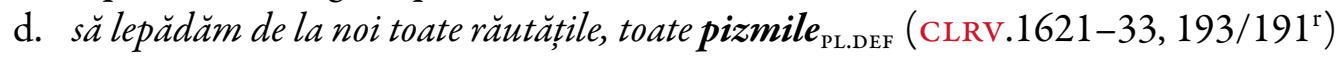

'to give up on all kinds of evil, all the envy'

e. avînd Vladulpîrcălabulpîiri $i_{\mathrm{PL}}$ si gîllcevi $i_{\mathrm{PL}}$ cu Stoica logofătul (DRH,B.1645, XXX) 
'as Vlad the nobleman and Stoica the nobleman denounced one another and fought with one another'

f. la $_{\text {clevete }} \mathrm{PL}_{\mathrm{PL}}$, la zavistii $\mathrm{PL}_{\mathrm{PL}}$ la vrăjbi $\mathrm{i}_{\mathrm{PL}}$ și goniri $_{\mathrm{PL}}\left(\mathrm{AIP} .1705,4^{\mathrm{r}}\right)$

'for gossip, for jealousies, for quarrels and oppressions'

g. de faptele sale cu amestecaturile $e_{\mathrm{PL} . \mathrm{DEF}}$ ce avuse cu Racoții? (CLM.1700-50, 295`)

'of his deeds with the intrigues he had had with Racoții?'

h. Că pe acea vreme ave gîlcevi $i_{\mathrm{PL}}$ cu sffedzii (NL 1750-66, 44)

'because in that time he was quarrelling with Swedes'

Whenever they occur, plural forms are disambiguated either through the selection of the plural article (blindeațele 'gentleness.PL.DEF', cinstele 'honour.PL.DEF', dragostele 'love.PL.DEF', pacile 'peace.PL.DEF'), or through their agreement with a proper adjective, a quantifier, a demonstrative or a possessive adjective, to whom they impose the feminine plural (multe cinste 'many.F.PL honours.F.PL', toate cinstile 'all.F.PL honours.F.PL.DEF', dragostile muierești 'love.F.PL women.F.PL' [women's loves], pacile tale 'your.F.PL peace.F.PL').

As far as the GEN-DAT.SG of abstract feminine nouns is concerned, old Romanian already shows the syncretism specific to Romanian feminine nouns and adjectives, namely GEN-DAT.SG $\equiv$ NOM-ACCGEN-DAT.PL. Since the plural of these nouns, when used, oscillates, the GEN-DAT.SG form reflects the same variation encountered in the plural, meaning that the genitive-dative is either invariable ${ }^{11}[(12 \mathrm{a}-\mathrm{b})$ : cinste (i) 'honour.GEN $\equiv \mathrm{DAT}$ '], or variable, with a form that is syncretic to the plural $[(12 \mathrm{c}-\mathrm{d})$ : cinsti(i) 'honour.GEN $\equiv \mathrm{DAT}^{\prime}$; (12e): foameți(ei) 'hunger.GEN $\equiv \mathrm{DAT}$ '].

(12) a. unii dulceți și unii cinste GEN $_{\text {GAAT.sG }}\left(\mathrm{CC}^{2} .1581,319 / 17\right)$ 'to some gentleness and some honour'

b. mărirea aceștii cinste $_{\text {GEN.SG }}$ (Mărg.1691, 64 )

'the increase of this honour'

c. te aleasă Dumnedzău și te spodobi aceștiia cinsti $_{\text {DAT.sG }}$ (FN.1693-704, 371)

'God chose you and considered you worthy of this honour'

d. te-au spodobit (=a considera demn) cinstii $i_{\mathrm{DAT} . \mathrm{SG} . \mathrm{DEF}}$ aceștiia a firea împărat (FN.1693-704, 376)

'they considered you to be worthy of the honour of being emperor'

e. anii foameției $i_{\mathrm{GEN} . S G . D E F}(\mathrm{PO} .1582,112)$

'the years of hunger'

Frâncu (2009, p. 28) notices that, although they are present in different types of texts, pluralized abstract forms have a higher frequency in the northern regions. For example, the following pluralized abstracts occur in CV.1563-83, many of them disappearing from the language at a later stage; see examples such as: PL lăsăciuri 'forgiveness.PL' (Cv.1563-83, 39v/6); PL urăciuri(le) 'blessings' (cv.1563-83, 62 /14); PL clevete(le) 'accusations, defamations' (Cv.1563-83, 37 /6, 72 /11); PL milosti 'mercy.PL' (CV.156383, 63v/7); PL sfade(le) 'quarrels' (CV.1563-83, 63v/14); PL strasti 'passion.PL' (CV.1563-83, 70v/14); minnicii(le) 'immoral behaviour.PL' (cV.1563-83, 79'r/12; < mîniac; apud Costinescu, 1981, p. 190); pîşenii(le) 'arrogance' (cv.1563-83, 65 /14; < pî̀sen 'arrogant'; apud Costinescu, 1981, p. 192); scîrbi 'sufferance' (CV.1563-83, 70 $\left./ 10,75^{\mathrm{r}} / 5\right)$.

In standard modern Romanian, the pluralized forms of abstract nouns are less frequently used, as these nouns behave like singularia tantum, so that the situation of invariability under (9) only occurs for the singular (see the forms recommended by the DOOM${ }^{2}$ : cinstei 'honour.GEN $\equiv \mathrm{DAT}$ ', foamei 'hunger.GEN $\equiv$ DAT', foametei 'hunger.GEN $\equiv$ DAT', onoarei 'honour.GEN $\equiv$ DAT', setei 'thirst.GEN $\equiv$ DAT'). Even when they are used in the plural, pluralization is associated with different concrete meanings and even with gender changes (see onoare F $_{\mathrm{F}}$ onor $_{\mathrm{N}}$ - onoruri $_{\mathrm{N}}$ 'honour.SG - honour.PL').

\footnotetext{
${ }^{11}$ In the case of determined forms, the syncretism NOM-ACC.SG vs GEN-DAT.SG is resolved by the usage of the enclitic determiner (cinstea - cinstei 'honour.NOM $\equiv \mathrm{ACC} . \mathrm{DEF}-$ honour.GEN $\equiv$ DAT.DEF').
} 


\section{The pluralization of the collective noun zestre 'dowry'}

This collective noun of Latin origin (< DEXTĔR $17^{\text {th }}$ century with syncretic forms for both numbers [(13a) vs (13b)]. Plural forms are the most frequent $(13 \mathrm{~b}-\mathrm{d})$; see the distribution of singular and plural forms in the table below. Distinguishing the singular from the plural is often done contextually, through the selection of a specialized article form $(d z e a s t r e l e$ 'dowry.F.PL.DEF') or through adjectival agreement (altă dzeastre 'another.F.SG dowry' vs aceale dzeastre 'those.F.PL dowries').
a. să nu mai ceară altă dzeastre ${ }_{\mathrm{SG}}(\mathrm{PA} \sim 1630,570)$ 'not to ask another dowry'
b. nu va lua nemică dentr-aceale dzeastre ${ }_{\mathrm{PL}}$ (Prav.1646, 113/27) 'he will take none of that dowry'
c. să-şi ia și dzeastrele $e_{\mathrm{PL}}$ toate cîte va fi avut (PA 1630, 511) 'to also take her dowry, all that she might have'
d. să-și piardză muiarea toate dzeastrele $\mathrm{PL}_{\mathrm{L}}$ ce va fi avînd (Prav.1646, 110/3) 'for the woman to lose all the dowry that she might have'

\begin{tabular}{cccc} 
Text & dzeastrele F.PL & dzestre(a) F.SG & $\begin{array}{c}d \text { zestre AMBIGUOUS } \\
\text { (SG or PL?) }\end{array}$ \\
\hline PA 1630 & 41 & 1 & 10 \\
Prav.1646 & 30 & 3 & 2
\end{tabular}

Table 1: The plural form of the collective noun zestre 'dowry'

More than a century later, in Prav.1780, the singular forms are predominant (the singular of a collective noun): 8 attestations of the determined feminine form zestrea/zestria 'the dowry'(14a), 5 occurrences of the feminine form without a determiner, with the form being disambiguated as singular through agreement (14b), 5 forms of GEN-DAT.SG zestrii/zestriei 'dowry.F.SG.GEN $\equiv$ DAT' (14c) and only one plural form (14d). The plural and the GEN-DAT.SG forms indicate the differentiation of the PL form (zestre 'dowry' zestri 'dowry.GEN $\equiv$ DAT.SG'). For modern standard Romanian, DOOM ${ }^{2}$ does not indicate the plural form, which means that the noun is used as a singulare tantum.

(14) a. mulțumită pe zestrea ce va fi luat (Prav.1780, 98/27)

'satisfied with the dowry that he may have taken'

b. s-au multumit pe acea zestre (Prav.1780, 94/6-7)

'they were satisfied with that dowry'

c. cîte lucruri de ale zestri să vor găsi (Prav.1780, 94/17)

'how many items that are part of the dowry will they find'

d. cheltuielele zestrilor (Prav.1780, 96/1)

'the costs of dowries'.

\section{Conclusions}

- The phenomenon of pluralization of mass, abstract and collective nouns is extremely frequent in old Romanian.

- The pluralization of mass and abstract nouns often triggers a change in meaning and leads, in the case of mass nouns, to their 'demassification', and, in the case of abstract nouns, to 'de-abstractization' / 'concretization'. 
- Daco-Romanian has developed a specialized ending, -uri, for the pluralization of mass nouns and, implicitly, for the change in meaning.

- The evolution of -uri (from the plural of feminine nouns - the type mătăsuri 'silks', verdețuri 'herbs', and from the plural of neuter nouns - the types metaluri 'metals', vinuri 'wines') shows a special process, that consists of converting a grammatical (plural) morpheme into a lexical one.

- Simultaneously, the ending - uri becomes ambiguous, as it expresses, cumulatively, two values: a grammatical (plural) one and a lexical (derivational) one.

\section{Bibliography}

\section{A. Corpus}

A.1620 = Alexandria, in Zgraon, Fl. (ed.), Cele mai vechi cărți populare in literatura română, vol. 11, Fundația Națională pentru Știință și Artă, București, 2006.

AD.1722-5 = Antim Ivireanul, Didahii, in Opere, ed. G. Ștrempel, Editura Minerva, București, 1972.

AIP.1705 = Antim Ivireanul, Învățătură pentru taina pocăințiii, in Opere, ed. G. Ștrempel, Editura Minerva, București, 1972, p. 347-351.

вв.1688 = Biblia adecă Dumnezeiasca Scriptură a Vechiului şi Noului Testament, tipărită întîia oară la 1688 în timpul lui Șerban

Vodă Cantacuzino, Domnul Țării Românești, Editura Institutului Biblic, București, 1977.

CazV.1643 = Varlaam, Cazania, ed. J. Byck, Fundația Regală pentru Literatură și Artă, București, 1943.

CBuc.1749 = Carte întru carea să scriu mincările, ed. I. Constantinescu, Editura Fundației Culturale Române, București, 1997. $\mathrm{CC}^{1} .1567=$ Coresi, Tîlcul evangheliilor și molitvenic românesc, ed. V. Drimba, Editura Academiei, București, 1998.

$\mathrm{CC}^{2} .1581$ = Coresi, Cartea cu invvățătură, ed. S. Pușcariu \& Al. Procopovici, Atelierele Grafice Socec, București, 1914.

CDicț.1691-7 = Teodor Corbea, Dictiones latina cum valachica interpretatione, ed. A.-M. Gherman, Editura Clusium, ClujNapoca, 2001.

CL.1570 = Coresi, Liturghierul lui Coresi, ed. Al. Mareș, Editura Academiei, București, 1969.

CLM.1700-50 = Miron Costin, Letopisețul Țărîi Moldovei. Opere, ed. P. P. Panaitescu, Editura de Stat pentru Literatură și Artă, București, 1958.

CLRV = Mareș, Al. (coord.) (2016). Crestomația limbii române vechi, vol. I (1521-1639), Editura Academiei Române, București.

Cron.1689 = Cronograf tradus din grecește de Pătraşco Danovici, 2 vol, ed. G. Ștrempel, București, 1998.

cs.1609-18 = Codex Sturdzanus, ed. Gh. Chivu, Editura Academiei Române, București, 1993.

Ст.1560-1 = Coresi, Tetraevanghelul tipărit de Coresi, Brașov 1560-1561, comparat cu Evangheliarul lui Radu de la Mănicești.

1574, ed. Fl. Dimitrescu, Editura Academiei, București, 1963.

Cv.1563-83 = Codicele Voronețean, ed. M. Costinescu, Editura Academiei, București, 1981.

Dî = Chivu, Gh., Georgescu, M., Ioniță, M., Mareș, Al. \& Roman-Moraru, Al. (eds) (1979). Documente și însemnări românești din secolul al XVI-lea, Editura Academiei, București.

DPar.1683 = Dosoftei, Parimiile preste an, Iași, 1683, ed. M. Ungureanu, Editura Universității „Alexandru Ioan Cuza”, Iași, 2012.

DRH,B = Documenta Romanie Historica. B. Țara Românească, Editura Academiei Române, București, 1969: vol. XXII (16289); 1974: vol. XXIV (1633-4); 1985: vol. XXV (1635-6); 1998: vol. XXX (1645); 2003: vol. XXXI (1646).

DPv.1673 = Dosoftei, Psaltirea in versuri, in Dosoftei, Opere, 1, Versuri, ed. N. A. Ursu, Mitropolia Moldovei și a Sucevei, Iaşi, 1974.

DVs.1682-6 = Dosoftei, Viața și petrecerea sfinților, ed. R. Frențiu, Editura Echinox, Cluj-Napoca, 2002.

Ev.1642 = Evanghelie invătătoare, Govora, ed. A.-M. Gherman, Editura Academiei, București, 2011.

FD.1592-604 = Floarea darurilor, in Roman Moraru, Al. (ed.) (1996). Cele mai vechi cărți populare in literatura română, 1 ,

Editura Minerva, București.

FN.1693-704 = Foletul Novel. Calendarul lui Constantin Vodă Brîncoveanu (1693-1704), ed. E. Vîrtosu, Monitorul Oficial

și Imprimeriile Statului, București, 1942.

Mărg.1691 = Ioan Gură de Aur, Mărgăritare, ed. R. Popescu, Editura Libra, București, 2001.

NL 1750-66 = Ion Neculce, Letopisețul, in Ion Neculce, Letopiseţul Țării Moldovei și O samă de cuvinte, ed. I. Iordan, Editura de Stat pentru Literatură și Artă, București, ed. a II-a, 1959.

PA 1630 = Eustratie Logofătul, Pravila aleasă, ed. A.-M. Gherman, Editura Academiei Române, București (sub tipar).

po.1582 = Arvinte, V., Caproșu, I. \& Gafton, Al. (eds) (2005). Palia de la Orăștie, vol. 1, Textul, Editura Universității „Alexandru Ioan Cuza", Iași.

Prav.1646 = Carte românească de invățătură, 1646, ed. A. Rădulescu, Editura Academiei, București, 1961, p. 33-106.

Prav. 1780 = Pravilniceasca condică, 1780, ed. A. Rădulescu, Editura Academiei, București, 1957. 


\section{B. References}

Avram, M. (2003-2004). Despre desinența -uri la substantivele feminine, in “Analele Universității «Alexandru Ioan Cuza»”, t. XLIX-L, Studia linguistica et philologica in honorem D. Irimia, p. 63-70.

Candrea, I.-A. (1916). Psaltirea Scheiană, I, Introducerea, Atelierele Grafice Socec, București.

Chivu, Gh. (1993). Studiu introductiv, in Codex Sturdzanus, Editura Academiei Române, București.

Ciorănescu, A. (2002). Dicționarul etimologic al limbii române, Editura Saeculum I.O., București.

Costinescu, M. (1981). Codicele Voronețean, ediție critică, studiu filologic și studiu lingvistic, Editura Minerva, București. DoOM $^{2}=$ Dicționarul ortografic, ortoepic și morfologic al limbii române, Editura Academiei Române, București, 2005.

FCLRV = Popescu-Marin, M. (coord.) (2007). Formarea cuvintelor în limba română din secolele al XVI-lea - al XVIII-lea, Editura Academiei Române, București.

Frâncu, C. (1982). Vechimea și difuziunea lexicală a unei inovații comune dialectelor limbii române: desinența-uri la pluralul femininelor, in "Limba română", XXXI, 3, p. 199-212.

Frâncu, C. (2009). Gramatica limbii române vechi, Casa Editorială Demiurg, Iași.

GR = Pană Dindelegan, G. (ed.) (2013). The Grammar of Romanian, Oxford University Press, Oxford.

Maiden, M. (2014). Le rôle de la synonimie lexicale dans formation du pluriel flexionnel en daco-roman, in "Mémoires de la Société de Linguistique de Paris. Série tome XXII. Morphologie flexionnelle et dialectologie romane: typologie(s) et modélisation(s)", Peeters Publishers, Leuven, p. 35-50.

Maiden, M. (2015). The Plural Type cărnuri and the Morphological Structure of the Romanian Feminine Noun in Diachrony, in Pană Dindelegan, G., Zafiu, R., Dragomirescu, A., Nicula, I., Nicolae, A., Esher, L. (eds), Diachronic Variation in Romanian, Cambridge Scholars Publishing, Newcastle, p. 33-52.

Maiden, M. (2016a). Ambiguity in Romanian Word-Structure. The Structure of Plurals in -uri, in "Revue roumaine de linguistique", LXI, 1, p. 3-12.

Maiden, M. (2016b). Segmentarea cuvintelor în teoria morfologică și problema pluralelor românești în -uri, in Constantinescu, M., Dragomirescu, A., Nicolae, Al., Stoica, G., Zafiu, R. (eds), Perspective diacronice și comparative asupra limbii române, Actele celui de al XV-lea Colocviu Internațional al Departamentului de Lingvistică, Editura Universității din București, București, p. 11-7.

Nedelcu, I. (2013). Singularia tantum and pluralia tantum, in GR, p. 260-261.

Pană Dindelegan, G. (2009). Trăsături flexionare ale substantivului în româna actuală, in Pană Dindelegan, G. (coord.), Dinamica limbii actuale, Editura Academiei Române, București.

Pană Dindelegan, G. (2016a). The partitive phrase, in soR, p. 323-332, Crossref.

Pană Dindelegan, G. (2016b). Substantive invariabile și istoria lor, in Sala, M., Stanciu Istrate, M. \& Timotin, E. (eds), Pagini alese. Omagiu domnului Alexandru Mareş la împlinirea vîrstei de 80 de ani, Editura Univers Enciclopedic Gold, București, p. $164-178$.

Pană Dindelegan, G. (2017). Caracteristici ale sufixelor abstracte în limba română, volum omagial Maria Cătănescu (sub tipar). Ramat, P. \& Ricca, D. (2016). Romance: a typological approach, in Ledgeway, A. \& Maiden, M. (eds), The Oxford Guide to the Romance Languages, Oxford University Press, Oxford, p. 50-62, Crossref.

soR = Pană Dindelegan, G. (ed.) (2016). The Syntax of Old Romanian, Oxford University Press, Oxford, Crossref. 